\title{
1 Medium Regiment, (S.A.H.A.), S.A.A.
}

\section{by "Clinometer"*}

1st Medium Regiment, South African Artillery, (S.A.H.A.), to quote its original and correct title was established with headquarters in Cape Town with effect from 1st January 1946, in terms of Government Notice No. 839 of 18th April 1946.

Lt Colonel Norman Munnik, who was appointed to command the unit had originally been commissioned into the 1st Heavy Battery, Coast Artillery Brigade as a 2nd Lieutenant on 30th July 1935. When mobilised in 1939 he was posted to a succession of coastal batteries from Walvis Bay to Durban and in December 1941, was transferred to 3rd Anti-Aircraft Regiment, S.A.A. Later, when anti-aircraft regiments under S.A.A.F. control were established he was given command of 22nd A.A. Regiment, S.A.A.F.

In March 1943, he exchanged his post of a regimental commander for that of a Battery Commander and went north with the 1/12th Light A.A. Regiment, S.A.A. attached to the 6th S.A. Armoured Division as BC, 3/56 L.A.A. Battery, S.A.A.F.

He served throughout the Italian Campaign and with his unit suffered a few changes - the unit became an infantry company doing duty in the Appenines during the winter of 1944 and then became the 3rd Battery of 7/23rd Medium Regiment, S.A.A., equipped with 3.7 inch anti-aircraft guns.

When the Officer Commanding, Cape Command, Brigadier H.G. Wilmott had asked Norman Munnik in early 1946 to form and take command of 1st Medium Regiment he had agreed and, as an afterthought had asked how many personnel there were on strength. To his surprise he was told, "One, you!"

Nevertheless, in the first few months of its existence an Honorary Colonel was appointed. Government Notice No. 2234 of 25th October 1946, announced that, "Lieutenant Colonel Frank Whitmore Mellish, MC., is appointed Honorary Colonel of the 1st Medium Regiment, South African Artillery, (South African Heavy Artillery), with effect from 17th September 1946."

Frank Mellish's career had also led him from the
Coast Artillery through the S.A.A. and S.A.A.F. Anti-Aircraft organizations to HQ, S.A.A., 1st Infantry Division from whence he was transferred as a Colonel to the Reserve of Officers, Artillery Branch on 1st November 1949.

Despite the apparent creation of an entirely new unit there had previously been another regiment of the same title in the Union Defence Force and it had in fact emerged from the "South African Heavy Artillery Brigade", an Active Citizen Force unit formed in Johannesburg on 1st October 1939, expressly to perpetuate the memory of the South African Heavy Artillery batteries that fought in France in 1915-1918.

Six months after formation the designation of the S.A.H.A. Brigade was changed to 1 Medium Brigade, S.A.A. (S.A.H.A.), and full-time training began in July 1940. In Mid-October of that year, Headquarters and 1st and 2nd Medium Batteries embarked at Durban for service in East Africa.

The Brigade took part in the advance through Italian Somaliland and Abyssinia to Addis Ababa and detachments served with distinction in the Battle of the Lakes, and at Cambolcia and Amba Alagi. In July 1941, they sailed from Massawa for Egypt and shortly afterwards the Brigade was disbanded to provide reinforcements for the field regiments, almost the whole of 2 nd Medium Battery transferring to 7th Field Regiment, joining 1st Field Battery of Cape Field Artillery to help create the enlarged regimental organisation of 24 guns.

The third battery of the Brigade, known as 1st Heavy Battery had meanwhile remained in South Africa, being stationed successively at Potchefstroom, Sonderwater and Witbank. On 28th November 1941, the designation of the battery was changed to 1 Medium Battery and in September 1942, it was expanded to a regimental headquarters and two batteries and designated 1 Medium Regiment S.A.A. The unit was disbanded on 1st January 1944 .

The appointment of Lt Col Munnik as Officer Commanding 1st Medium Regiment and of the names and military background of OC's of other 


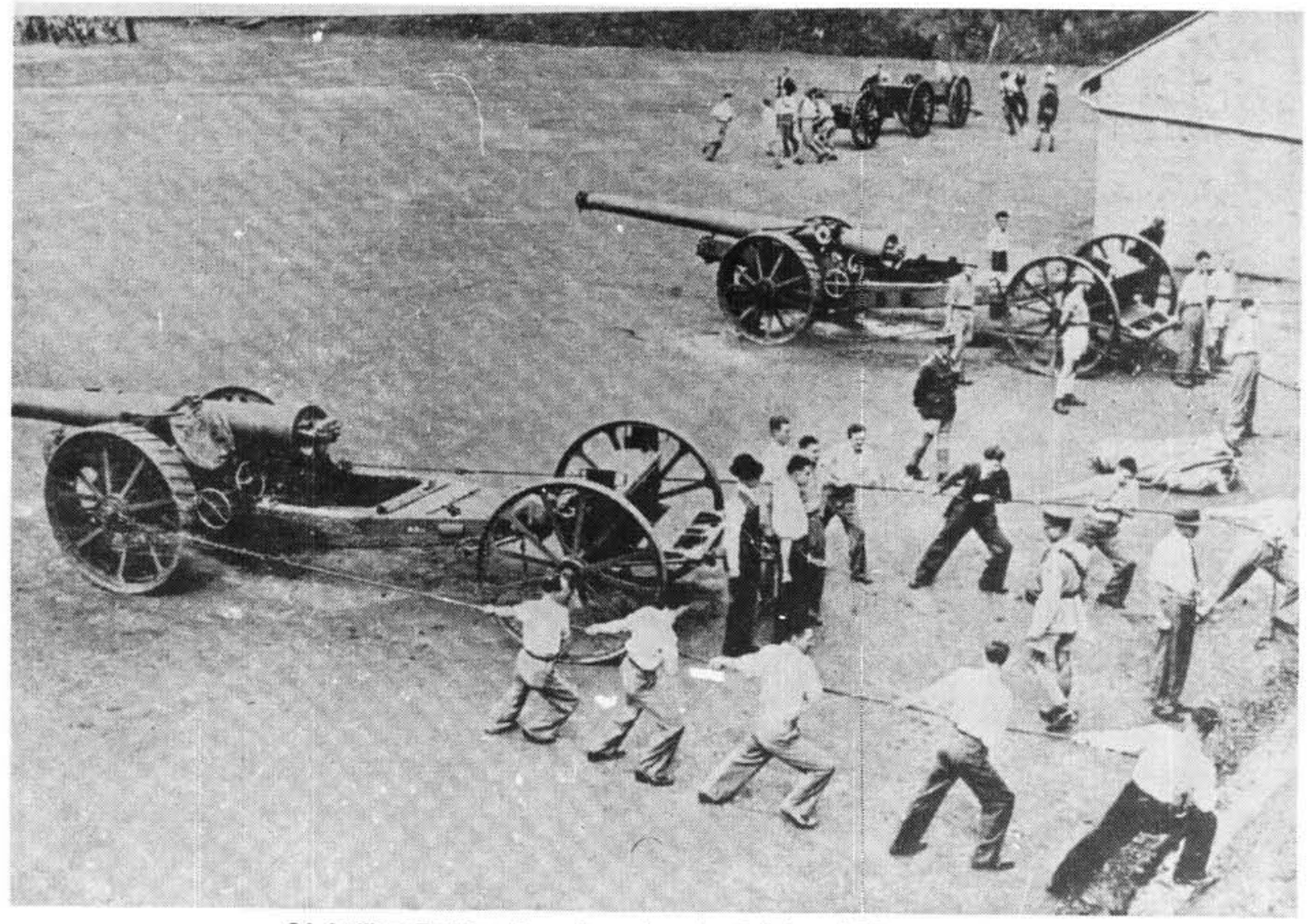

SA Artillery Training Recruits undergoing training with heavy artillery.

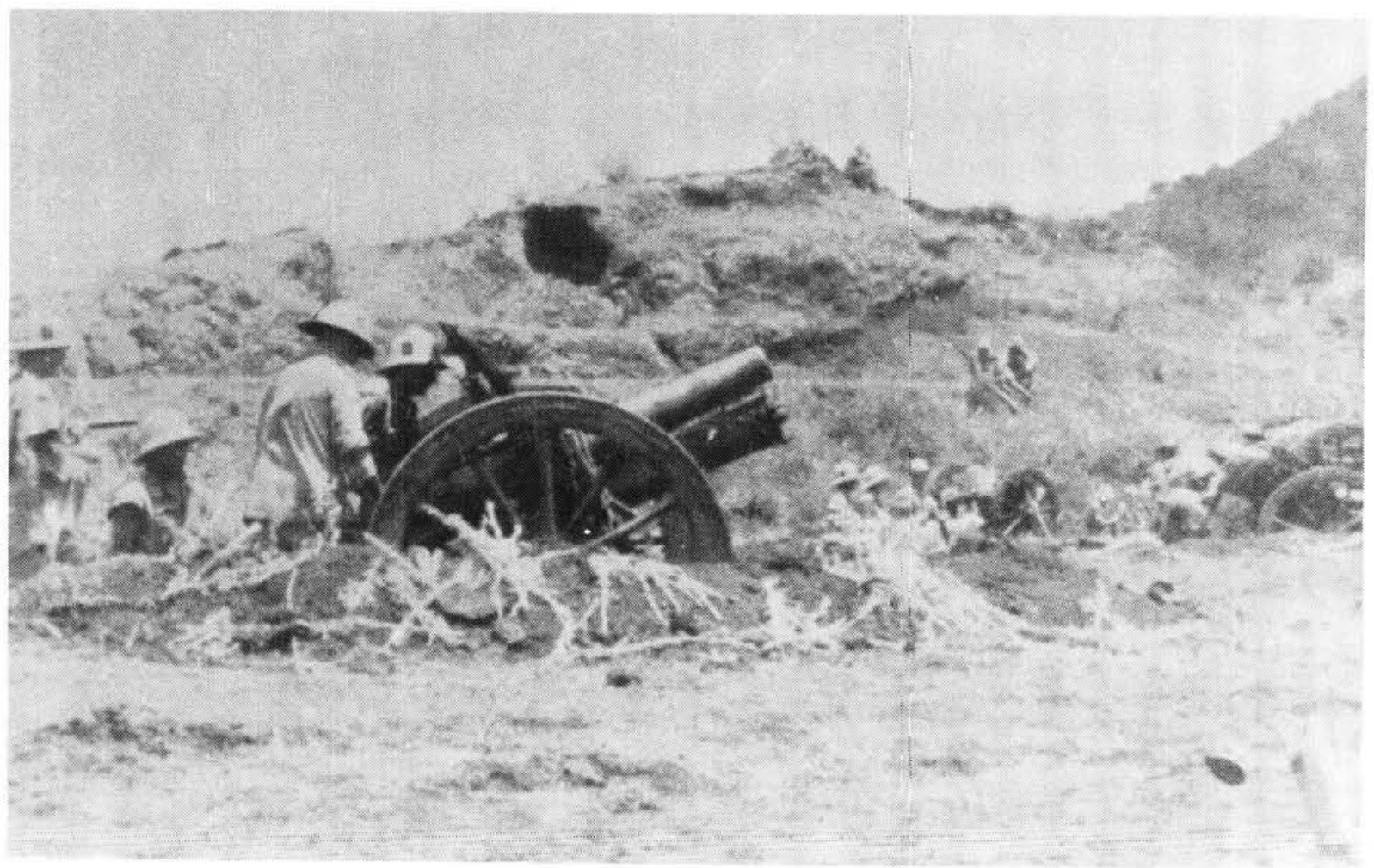

A battery of South African 4.5 inch howitzers comes into action at Ambo Alagi. (Copied from Orpen N: East Africa and Abyssinian Campaigns.) 
Cape Town Active Citizen Force Units, was announced in the Cape Argus of 19th June 1946.

Amongst the first officers recruited by the $\mathrm{OC}$ of the new Medium Regiment were Majors Hydenrych, Etherington and Lilford, Lieutenant (T/Capt) Crous and Lieutenant (T/Capt) B. O'Sullivan.

The year 1947 saw a small detachment of 1 Medium Regiment on parade near the quayside on the arrival of King George $\mathrm{VI}$ and the Queen in HMS Vanguard on 17th February, the officers in barathea with gloves and carrying swords on one of that summer's hottest days.

The unit later found a guard at Government House (now "Die Tuynhuis") whilst the Royal Family were in residence there and received a signed portrait of the King in remembrance of that honour. The photograph was some years later presented to the City of Cape Town by the remaining 1 Medium Officers, after the disbandment of the unit.
Later in the year the Mediums attended a continuous training camp at Potchefstroom and one former Officer recalls that "there were about 26 of us, barely enough for four gun detachments", while another remembers of that camp at Potchefstroom, or the following one, that armoured cars were used as OP vehicles at camp.

The year drew to a close with the RSM, WO1 C.O. de Gruchy being commissioned as a 2nd Lieutenant on 1st September and T/Capt J.W. King being posted to the General List, S.A.A.

In early February 1945, 2nd Lieutenant C.G. Bell resigned his commission and on the 8th of that month Captain W.M. (Gibbo) Gibbs was appointed Admin and Training Officer as a replacement for Lieutenant Roxie Roux who was posted to 4th Field Regiment, S.A.A., Potchefstroom, after being Admin and Training Officers, 1 Medium Regiment, since 2nd June 1946. He had been transferred to the Mediums from the S.A. Military College under authority of Force Order 4066 of 24th February 1949.



1 Medium Regiment S.A.A. (S.A.H.A.) Training Camp at Potchefstroom 17 May 1947 to 15 June 1947. 
Gibbo Gibbs is known to have served in $1 / 6$ th Field Regiment S.A.A., (P.A.O.C.F.A.) in Italy and then to have been transferred to 15th Field Regiment, in which unit he was promoted to T/Captain on 1st January 1945. He was later reposted to 1/6th Field Regiment from whence he was transferred on 27th August 1945, to Headquarters Cape Command, "Ex North", as it was termed in Force Order 4066, being appointed Adjutant of 1st Field Regiment, S.A.A., (P.A.O.C.F.A.) almost exactly three months later.

Having successfully applied and been granted an appointment in the S.A. Permanent Force on 1st May 1946, he was transferred to 4th Field Regiment, S.A.A., in September, with the substantive rank of Captain. It was from 4th Field Regiment that he went to the Mediums.

Captain Gibbs was awarded the Efficiency medal in September 1952.

After leaving 1 Medium Regiment in 1953 when Admin and Training Officers were withdrawn from all ACF units in the general re-organization late that year, Gibbo disappeared into the limbo of Permanent Force activity and eventually served in Korea with a Royal Artillery mortar regiment. In recognition of distinguished services whilst attached to the Commonwealth Division he was admitted to the Military Wing of the Order of the British Empire.

In those early days after the last war Active Citizen Force units boasted not only an Admin and Training Officer, but also a Permanent Force NCO. Staff Sgt Reg Presmeg who was very much part of the unit was replaced by Staff Sgt P.F. (Platkop) van der Merwe in 1952.

In his quest for experienced Officers, Lt Col Munnik persuaded "Vossie" Vosloo to join the unit and in a series of paper moves, War Substantive Captain A.G. Vosloo, M.C. was transferred from the General List, S.A.A., with the substantive rank of Captain with effect from 14th April 1948, with seniority of rank from 16th July 1943. In another Force Order, Captain Vosloo was appointed 2IC and Temporary Major, also from 14th April, "pending qualification and whilst holding the appointment".

The administrative backlog in the Union Defence Force must have been enormous for it was only announced in Force Order 4303 on 17th April 1950, that:
"The King has been graciously pleased on the advice of His Majesty's Ministers for the Union of South Africa, to approve the following awards in recognition of gallant and distinguished service at Tobruk in 1942."

and in the list was the award of the Military Cross to Captain Abraham Gabriel Vosloo, and to an Officer who had joined the other ACF Artillery Regiment in Cape Town, Captain William Burr Knott of 1 st Field Regiment, S.A.A., (P.A.O.C.F.A.).

The unit featured more than once in Force Orders that year, commissions as 2 nd Lieutenants being granted to WO2 Zirk Nel (3rd May) and to Sgt Philippus van Onselen and Bdr Geoffrey Canning, both on 1st August 1948. Tom Walters was commissioned on 1st November 1948, one of the first to be appointed a 2nd Lieutenant after serving "on paper" for six months as a Gunner and a volunteer. He was also one of the first of the legal fraternity to be commissioned and was closely followed by 2nd Lieutenants Hedley Salmon (2 November) and Peter Leigh (29th December 1948).

A cause for celebration in the Officers' Mess was the announcement by means of Government Notice 2133 of 1948 which appeared in Gazette 4039 of 8th October, of the award of the Efficiency Decoration to Lt Col Norman Elijah Munnik. Not for the first, and nor the last time, was a junior Officer detailed to follow the OC home to ensure that he arrived safely.

Five members of the unit were amongst a number of NCO's and Gunners who attended a three weeks Number One course at the School of Artillery and Armour, Potchefstroom in August/September with WO2 J.P. Lovett to be commissioned as Quartermaster with the rank of Lieutenant on 25th January 1949, coming first on the course.

Early in 1949 all those who had been ballotted to commence military training on 1st July of that year, reported to the New Drill Hall, Tennant Street, Cape Town, for medical examination and attestation into the Active Citizen Force. Each unit in Cape Command had its table and force of "recruitment personnel" to entice the new boys to join "their" unit and, who should be there to talk three firm friends from Wynberg Boy's High School into joining the Medium Gunners but one of their former classmates and also school cadet detachment Sergeant Major Lionel Hawtrey, who 

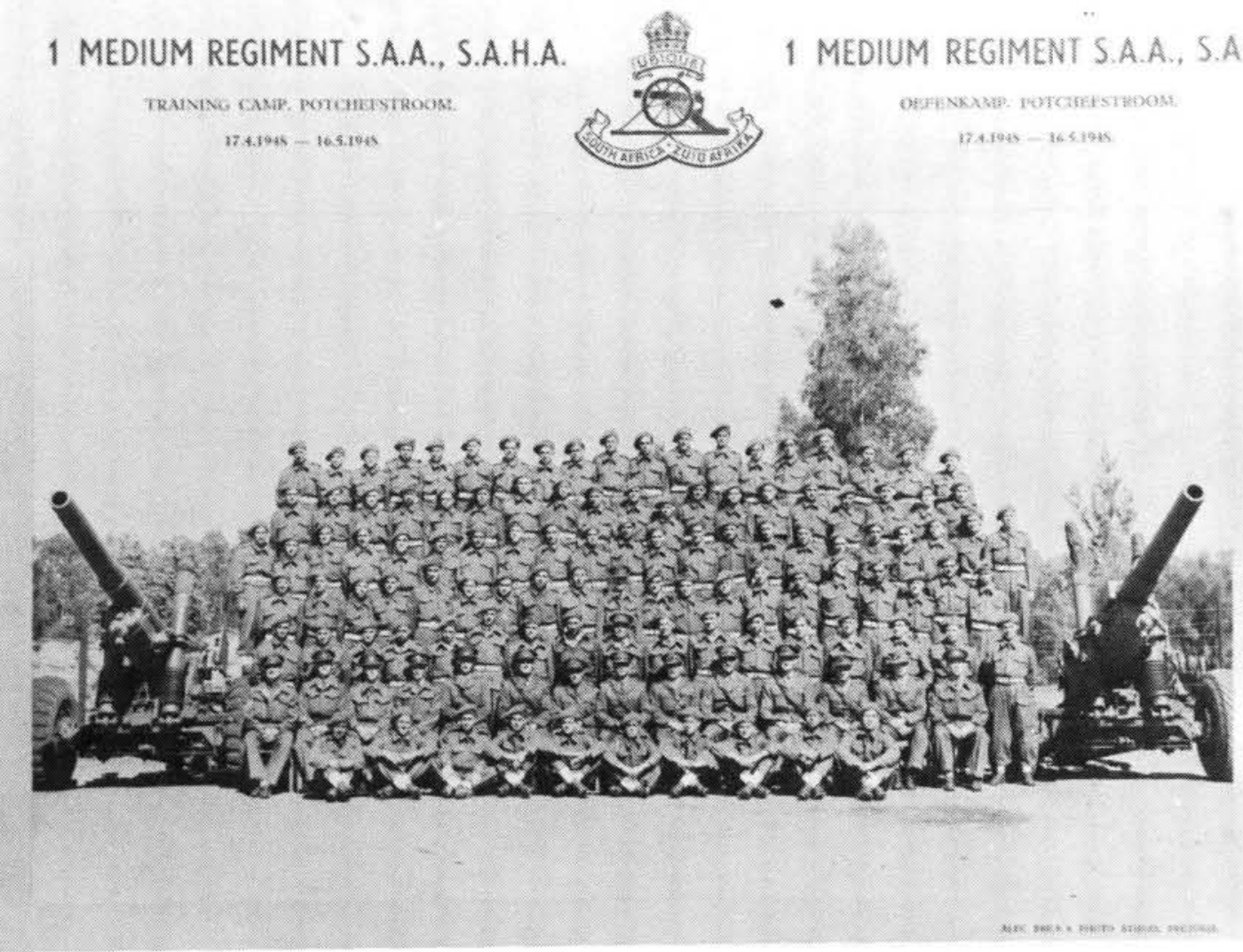

1 Medium Regiment S.A.A. (S.A.H.A.) Training Camp at Potchefstroom.

unbeknown to the school or the regiment had been serving in 1 Medium Regiment whilst still a scholar and had attained the rank of Sergeant.

Needless to say, there were soon three new Gunners in Lionel Crook, John Creed and Vernon Meyer and they were attested, together with Clive Francis from 1st July 1949, the only matrics in a group of over ninety recruits that year.

Creed had, however, been declared medically unfit as he was blind in one eye. It was inconceivable to the three, who had spent a number of years together at school, that they should be parted and having discovered that one could voluntarily join the ACF, they one day entered the Castle, found the medical rooms and copied down the eye chart. Creed applied to do voluntary military service, was called to undergo a medical examination and passed with flying colours!

Months later he was summarily instructed to appear for another medical because Defence Headquarters with a surprising degree of efficiency had matched up the two medical reports, and this time his blindness was again discov- ered and he was declared medically unfit. He continued to soldier on, however, for once Norman Munnik learned the full story he put forward a strong motivation and obtained permission for Creed to remain on strength. The latter could never be commissioned but eventually became RQMS.

In those years Citizen Force units did their own recruit training and soon after the beginning of July the new recruits were each kitted out with a winter uniform consisting of the rough British style bunny jacket and trousers, boots and anklets. This was worn with a web belt and a funny kind of beret. The jacket was generally worn closed up to the neck and the trousers could only comfortably be held up with braces.

Summer dress consisted of Polo helmet, shirt with rolled up sleeves, shorts and web belt, and boots $\mathrm{R}$ and $\mathrm{F}$; anklets, canvas; and hose tops; $\mathrm{a}$ cool and practical uniform. For ceremonial occasions in summer, the above dress was augmented by a shirt and tie and a well-starched and ironed bush jacket, quite the best ceremonial uniform the S.A.D.F. has yet had. 
After receiving their kit the recruits were plunged into four or five months of training in all aspects of foot and rifle drill, parades taking place every Tuesday and Thursday night on the old early morning market in Sir Lowry Road (now occupied by the Good Hope Centre) from $20 \mathrm{h00}$ to $22 \mathrm{~h} 00$. Those regimental instructors certainly knew their drill but the most feared man on the parade ground was Lieutenant Colin de Gruchy, the former RSM who had a tongue like a whiplash and the ability to drill a squad until they literally quaked with fear.

Unbeknown to the recruits, Defence Force Route Orders prescribed a maximum of 8 days noncontinuous training (or 64 hours) for recruits with 42 days continuous training for the latter and 15 for trained men; and non-continuous training time was always stretched far beyond its prescribed limit.

In addition to foot and rifle drill, and lectures when it rained, mustering training took place at Youngsfield where the unit had a hangar with all its soft vehicles, jeeps, Ford 1 ton radio vehicles and 3 ton cargo, Mack gun tractors, 5.5 inch guns and all associated stores and equipment. The new recruits learned gunnery, signals on the No. 19 set (search for the zero beat), driving and survey.

Training took place on Saturdays and two full Saturdays per month for part of the year were normally allocated for such parades. There was no pay for all these duties.

Young men at that time did not earn more than an average of R30-R40 per month and could not afford motor cars or even motorcycles and so recruits were issued with bus and train tickets to enable them to attend parades. Discipline was very strict, the OC was a stickler in this respect and anyone not attending a parade quickly found himself in court and relieved of a few pound stirling - and it hurt. It did not happen very often as youth then were a lot more selfdisciplined.

Lieutenant (T/Capt) Bernard O'Sullivan transferred to the Reserve of Officers on 19th January 1949, relinquishing the temporary rank of Captain in doing so. To fill the gap so created, WO2 Colin Coull was commissioned as a 2nd Lieutenant. C.O. de Gruchy had been appointed Adjutant and to be a Lieutenant whilst holding the appointment from 7th March 1949. His promo- tion to substantive Lieutenant became effective on 1 st September of that year.

Force Order 4176 of 19th October 1949 in fact announced that as Lieutenants C.O. de Gruchy, R.G. Jacobsen and $Z \mathrm{Nel}$ had qualified on the Troop Officers Course over the period 19th to 24th April 1948, they were exempted from reexamination for promotion from 2nd Lieutenant in the Active Citizen Force. The reason given was that the syllabus of both the Troop Officers Course and the 2nd Lieutenant Qualifying Course was the same.

Another officer was lost when 2nd Lieutenant L. Cowan resigned his commission with effect 8 th August.

Active Citizen Force units were socially and militarily active and they played frequent games of rugby against each other during the season and against clubs such as Olympics, Kelvin Grove, etc. Between 19th August and 28th September there were four such games, played on Wednesday afternoons or Sunday mornings.

The highlight of each season was the game against Cape Field Artillery, for both sides were determined to win. In one game played at the S.A.C.S. Leeuwenhof field on Wednesday 28th September, several members of both sides suffered injuries and Lieutenant Peter Leigh of the Mediums received a broken arm. The excitement during the match was tremendous but as usual all 30 players trooped off the field best of friends.

\section{A typical side was:}

\section{Gnr Crook L.A. \\ Lt P.L. Leigh \\ Major A.G. Vosloo \\ Lt G.E. Canning \\ Sgt Saacks L.S. \\ Capt W.M. Gibbs \\ Bdr Lemensich B.A. \\ Lt J.P. Lovett \\ Bdr du Plessis L. \\ Lt N. Gow \\ Lt T. Walters \\ Lt H. Salmon \\ Lt Z. Nel \\ Lt C.O. de Gruchy}

The Permanent Force Training NCO, Staff Sgt W. Presmeg seemingly always filled a reserve slot with Bdr Edgecombe and WO2 Heydenrych. 
It is interesting to note that in those far off days the initials of other ranks always appeared after their surname while Officers were priviledged to have their initials appear before their surname in all orders, notices, etc.

1950 was a busy year with 1 Medium Regiment following Cape Field Artillery into camp as the second gunner regiment to use the newly opened military camp at Oudtshoorn, then under command of Major R. Bodley.

February is a very hot month at Oudtshoorn and facilities at the camp were of the barest minimum. For the recruits, accompanied by the RSM, WO2 John Rath and WO2 J.A. Heydenrych and WO2 C.J. Booysen, it was almost like hell on earth.

The parade ground had been scraped out of the soft red dusty earth and had not been otherwise surfaced, the dust having been pushed to the sides of the ground. There was not a blade of grass in the camp and to eat in the conditions pertaining in the Gunners' Mess was something akin to being on a survival course. The food was like slop and two of the recruits, Francis and Meyer refused to eat there, living instead on items purchased from the YMCA - who had a canteen in the camp - until after 10 days their money ran out.

The toilets worked on the bucket system and it was an experience to enter the corrugated iron enclosure in the midday temperature which averaged $44^{\circ} \mathrm{C}\left(93^{\circ} \mathrm{F}\right)$ to attend to one's daily task.

A short, dark and extremely hard case Sergeant Major was responsible for parade ground drill and he loved to take the recruits into the corner of the parade ground where the dust lay, powdery and thick, and order, "MARK-TIME. LIFT THOSE KNEES!", keeping his squad there until the dust had risen over their heads. Every lunch break and day-end he would select one member to march the squad back to barracks and woe betide them if it were not done perfectly; the dust-streaked, sweating gunners would go through the whole routine anything up to four or five times before being allowed to reach their bungalow.

In the evenings particularly, the recruits would arrive at their bungalows to find everything covered in a layer of red dust; pillows, sheets and blankets were unrecognisable and all the spit and polish of the early morning had been undone by the wind that came up every afternoon and literally whirled through the camp.

It was not the only "hazard" they faced. All the different musterings were housed separately and in the bungalow housing the Technical Assistants and the Surveyors, Gnr Malan one evening stood on a scorpion. It was a big one and the pain must have been intense, for his screams were something to be heard and in the halfhour before a Medical Officer appeared his leg had swollen to double its size. Everyone looked at it with awe and all were thereafter very careful.

The TA bungalow NCO was Bdr W.F. Beineke and his greatest problem was that of controlling Gunner Farmer who despite all efforts always succeeded in getting into town each night and in arriving back late at night undetected but always heavily soaked with liquor. And he always switched on all the lights and woke everyone up with his noisy getting-to-bed routine. A remarkable man, for he was neatness personified and no one could ever understand how, even each day in the field, he could appear in an overall or other uniform that looked as though it had just been washed, starched and ironed.

Recruit camp was slightly more than three weeks at the end of which the trained men came in for 15 days and the continuous training period ended with a spell on the range, doing "dry runs" and live shell firing first with 25 pounders (now $88 \mathrm{~mm}$ ) and on the last day, with the 5.5 inch $(140 \mathrm{~mm})$ guns organic to the unit. One year the unit also used 3.7 inch howitzers.

Dog Troop (in accordance with the then current phonetic alphabet) Gun Position Officer was 2nd Lieutenant Tom Walters and the TA's were L/Bdrs Farmer and Crook. Their command post vehicle was a Ford 1 ton truck (it would be called a "bakkie" today) and at each gun position the TA's would have to haul out a table, $6 \mathrm{ft}$, wooden, folding; bench, wooden, folding; the artillery board, director and stand, technical paraphenalia, ie range tables, Sands graph, Stevens graph, target record books, etc., which would all be placed in prescribed positions and weighed down with stones to guard against the papers being blown away. The table would be set up alongside the truck with the bench right against the vehicle and the canvas side flap would be extended out to try and provide shade. 
All this at best possible speed, together with recording of zero lines in competition with other troops in an endeavour to be the first to report "READY" and thus secure the right for ones own guns to range onto the target.
For some reason there was a shortage of gun tractors and the impatient GPO of Dog Troop towed a 25 pounder into the first gun area just off the Calitzdorp road with the command post vehicle.

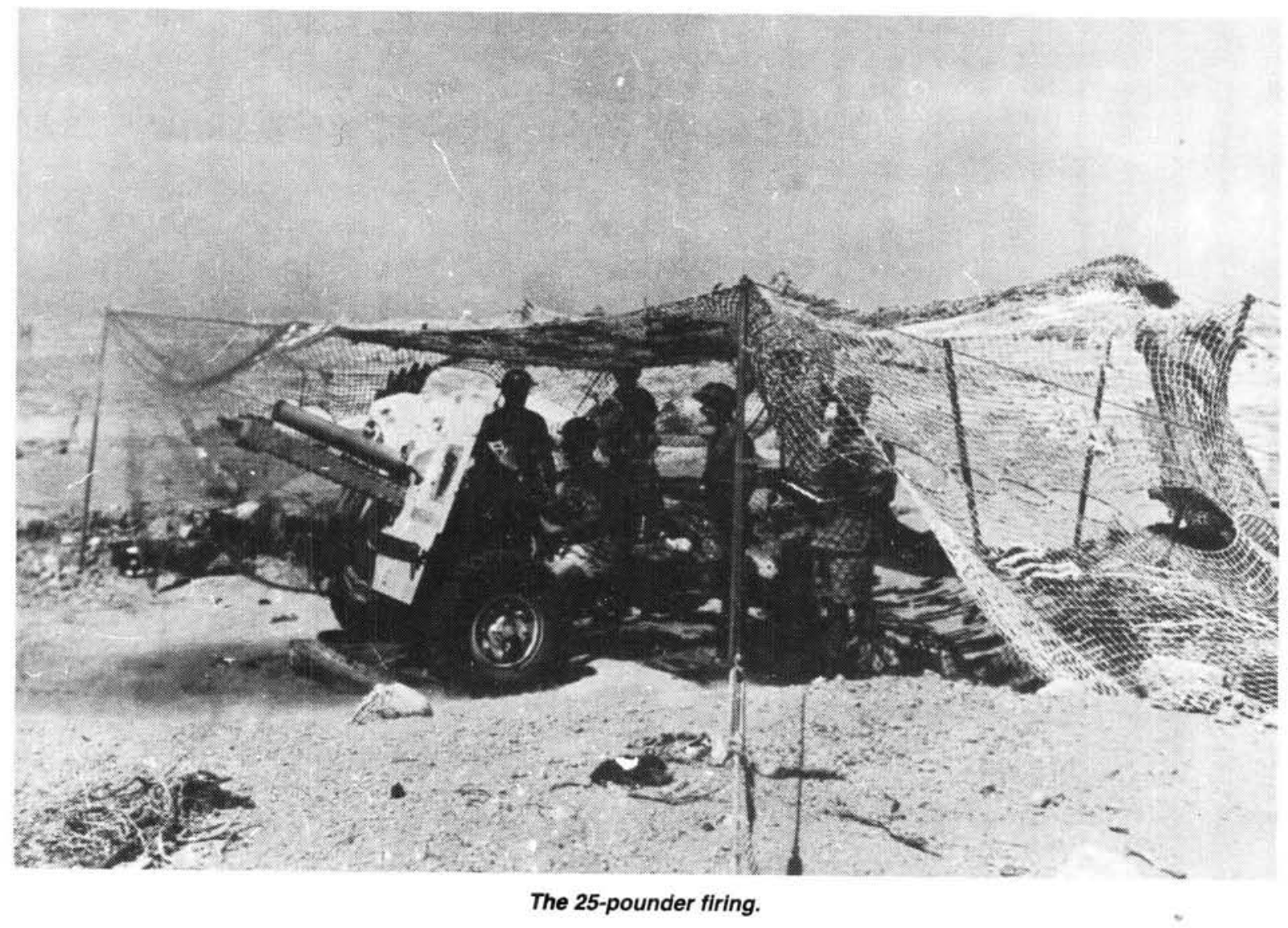

It was in this gun area on his first night ever in the South African veld that L/Bdr Crook was kept awake, not by the laughing of hyenas or other sounds of the African veld at night, but by the Officers who had gathered at Dog Troop for a friendly drink which ended with a noisy game of ring-a-ring-a-rosy round their camp fire at two that morning!

There were always two or three other units in camp at the same time and invariably 1 Medium seemed to be there with the Kaffrarian Rifles, Prince Alfreds Guard or First City. Inter-unit fights always broke out with troops running amok through each other's bungalows, overturning beds and emptying fire buckets and on one such night in 1950, prior to the Mediums departure for field exercises, things became a little out of hand when a unit retaliated violently to the horseplay, swinging socks filled with sand so that Permanent Force Personnel were called out to quell the near riot with tear gas.
Military life was pleasant for the Citizen Force in the 1950's. Work commenced at the reasonable hour of $08 \mathrm{~h} 00$ and ended at $16 \mathrm{~h} 30$ daily with every Wednesday afternoon free. There was no work on Saturdays or Sundays and this enabled the troops to go on excursions to the Cango Caves, or to Knysna for the weekend, whence they travelled crowded into a McKenzies Transport three-ton truck, taking rations with them and sleeping on the beach near The Heads.

The annual camp photograph for 1950 , a feature of all those training camps, showed that with Lt Col N Munnik there were 10 Officers, 6 Warrant Officers and 172 NCO's and Gunners, plus Capt Gibbs, S/Sgt Presmeg and 6 training NCO's.

The Officers included Major A.G. Vosloo, Captains J.J. Crouse and G.H.S. Etherington, Lieutenant R.G. Jacobsen, 2nd Lieutenants A.R. Boon, E.G. Canning, C. Coull, H. Salmon, H.P.M. van Onselen and T. Walters. The Warrant Offi- 
cers at that camp were G.L. Heydenrych, B.J. Bailie, B.W. Hawtrey, J. Rath, J.A. Heydenrych and C.J. Booysen.

2nd Lieutenant Jacobsen's promotion to Lieutenant became effective on 5th March 1950 during the camp.

Despite attending continuous training the spirit in this well motivated and happy regiment induced members to also attend courses in the same year and the latter part of 1950 saw WO2 Booysen, Bdr Beineke and L/Bdr Geldenhuys on a Platoon Weapons Assistant Instructors course at the Military College while WO2 Edgecombe, Bdr Silkstone and L/Bdrs Eady and Wentzel attended a Platoon Sergeants course in October. T/Captain Crouse and Lieutenants Jacobsen and $\mathrm{Nel}$ - the latter promoted to Lieutenant on 3rd May 1950 - qualified as Captains on Course A365 at the School of Artillery and Armour in November. Lieutenant de Gruchy had already qualified as a Captain in a similar course in May and had been promoted to substantive Captain from the 14 th of that month.

Finally, T/Capt Vosloo qualified as a Major on course 171G, Captain to Major, Qualifying, All Arms (ACF), in August 1950.

A new entry to the unit in June had been Captain H.C. Klopper, who transferred from the General List, ACF on the 13th. He had previously served in the 2nd Bn, Pretoria Regiment (Princess Alice's own), an Armoured Corps unit, and had been placed on the General List in September 1949 at his own request. He was not to remain in the unit for very long and will always be remembered for a $16^{\circ}$ switch in line whilst ranging with live shell. The Quartermaster, Lieutenant J.P. Lovett had resigned on 10th February, immediately before the unit went into camp and two more Officers were lost when 2nd Lieutenant Boon transferred to the General List on 3rd May before a further transfer to the Natal Field Artillery on 17th May, and 2nd Lieutenant N. Gow resigned his commission with effect from 26 September 1950 in terms of Section Thirty Five of the S.A. Defence Act.

They were replaced with Sergeant L.E. Hawtrey, commissioned on 10th August and Bombardier W.F. Reineke and Lance Bombardier L.A. Crook who were both commissioned with effect from 18th September 1950; "the last two named", so read a letter dated 20 December 1950, from
Cape Command, "are to retain their original order of seniority".

At the monthly meeting of Officers held in the Combined Artillery Officers Mess in the Castle in early November, seated in their brand new undress blues at the beautiful tables originally purchased by the Cape Garrison Artillery Trustees, both Reineke and Crook received a shock initiation into Citizen Force social activities when they were astonished to be instructed by their stern faced and gravel voiced Commanding Officer, who seemingly glared at them over the top of his spectacles, to go and learn to dance and to attend the Cape Command Spring Ball the following month. They had the temerity to raise their hands to indicate that they would not attend, with the excuse that they could not dance! The Ball held every year in the Lady Anne Barnard ballroom was a must for every Officer as was the signing of Visitors books at Cape Command, at Simonstown and at Government House, a fact of which Officers were constantly reminded.

In February 1951, 2nd Lieutenants Canning, Hawtrey, Salmon and Walters successfully completed their 2nd Lieutenant S.A.A. (fd) ACF qualifying course and in April the unit went to that year's continuous training camp at Oudtshoorn by road, taking with its own vehicles, guns and equipment in a convoy numbering about ninety vehicles and taking 3 days for the journey, stopping overnight at Riviersonderend and Mossel Bay.

A few weeks before departure it had been discovered that there were not enough drivers and a number of senior personnel, including all the Officers without licences, were hurriedly called in to Wingfield to undergo driving tests and obtain licences. The group reported on 20th March at the main gate in Voortrekker Road and were idling about waiting when an elderly Auxiliary Service guard asked "whether they were the bodies for the driving tests", volunteering the information that there was also a road sign test. On request he produced a chart and all concerned hurriedly copied down what each thought were the most important signs.

In the event they were not given a written test but were told, one by one, to climb into a medium artillery Mack tractor and drive it around the airfield!

The story of young 2nd Lieutenant Crook is a typical example. He had been driving Mack trac- 


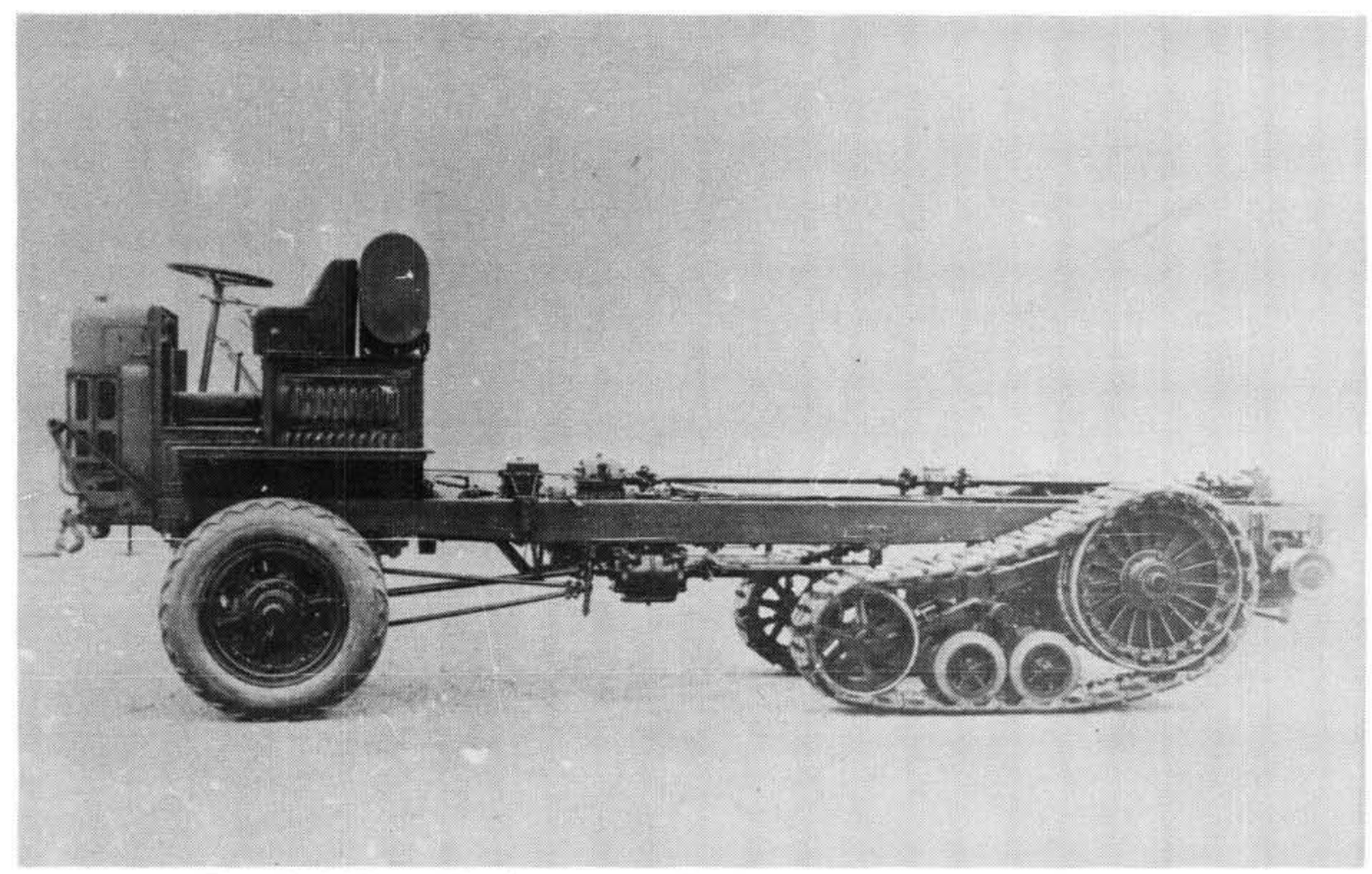

Four-wheel-drive roadless lorry tractor under trial as an alternative for Medium Artillery.

tors for weeks, ferrying troops from Youngsfield to Wynberg Station after parades - without a licence - and responded confidently to the Staff Sergeant's request to "drive around the airfield", and on arrival back at the start point responded just as eagerly to the instruction "STOP"! With its magnificent air brakes the Mack stopped, as is said, "on a tickey", and the driving instructor, without benefit of steering wheel to hold him, almost went through the windscreen!

With the admonition to in future, "pump the brake ligtly, Sir", the young Officer was issued with licence No. 155823 permitting him to drive a "Car, Van, Truck and Mack Tractor", and on reporting to Youngsfield on 18th April was allocated a Ford 3 ton GS Cargo to drive to Oudtshoorn, taking almost the whole journey learning to double declutch without grating the gears!

At an average speed of $20 \mathrm{~km} / \mathrm{h}$ the journey was boring in the extreme and drivers resorted to stopping with imagined faults and, later, running at a good speed to catch up. One young man even passed half the convoy whilst it was going up Sir Lowrey's Pass and a day later tried to break the speed record with a Mack tractor on a downhill stretch, with gun bouncing behind and detachment hanging on for dear life.
The regiment was welcomed with open arms at Riviersonderend and the Officers were accommodated free of charge at the local hotel, being provided with all the necessities for an enjoyable night's stay.

In the bivouac area near the hotel, Staff Sergeant John Creed was looking on as the troops wolfed down the stew he and his helpers in the Advance Party had prepared on the Crimean War soyer stoves, a stew of which a goodly part consisted of Army (dog) biscuits. The factual story revealed much later was that the biscuits, hard as rocks and taken direct from sealed airtight tins, had maggots in them. Throwing it all away would have severely depleted the rations so dog biscuits and bully beef went into a much enjoyed stew.

And later when the story was told, at least one man mailed a biscuit home complete with address and postage stamp.

To avoid both the dangerous Robertson Pass from Mossel Bay and the old pass from George to Oudtshoorn the unit was permitted to use the incompleted new Outeniqua Pass, a magnificent road despite lack of tar. Halting for the compulsory 10 minute break in a fertile valley at the bottom of the pass, the local farmer swamped 


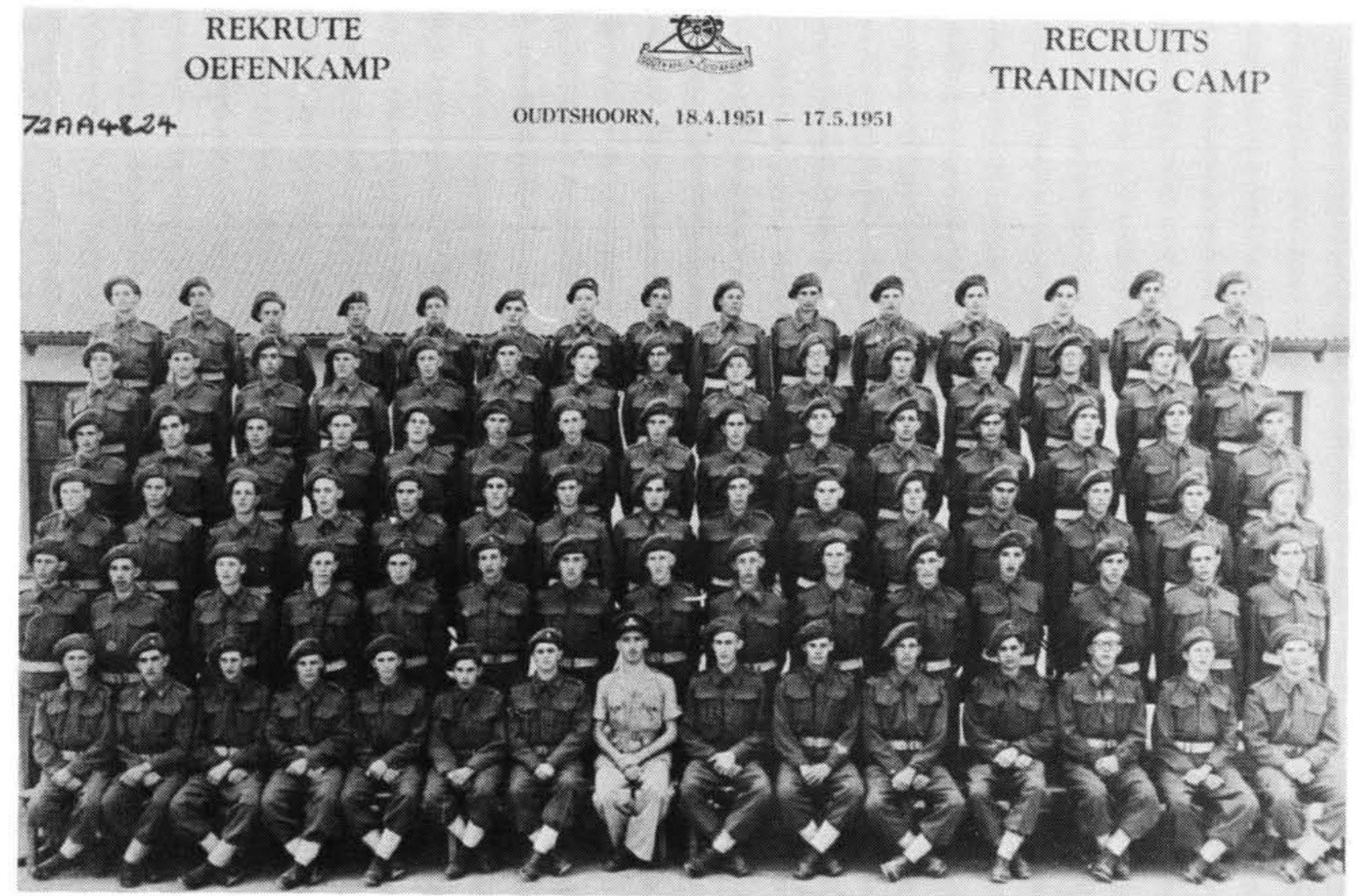

1 Medium Regiment S.A.A. (S.A.H.A.) recruits training camp at Oudtshoorn 18 April 1951-17 May 1951.

the troops with freshly picked fruit, a very welcome addition to 3 days of dry rations.

The final run-in to the military camp (now called a "base") was made over miles of dusty side roads between lucerne fields and ostrich camps, the dust rising so high and so thick that only the tops of radio aerials reminded one that there were vehicles ahead, and on arrival at the camp, gunners who had sat in the back of vehicles, could only be recognised as human by the whites of their eyes.

Continuous training that year was remarkable for two incidents. The Medium gunners were at gun drill prior to the final field exercises one day when an Air OP aircraft flew over the camp and from it two No 69 plastic grenades were thrown. One landed outside the cookhouse and one in the gun park, both failing to explode. Bdr Kruger, a Permanent Force training NCO who had been busy training the gunners, walked over and pushed the grenade with his foot and it exploded causing him severe injuries.

The second was the massive switch of 16 degrees made in two moves of 8 degrees each by the OP, Captain Klopper, when a gun of Dog
Troop, whose GPO, 2nd Lieutenant Crook, was ranging. Additionally there was an enormous change in range and in the middle of the engagement the artillery board had, as a result, to be set up completely afresh to suit the new grid reference.

Snakes abounded at Oudtshoorn and not a day went by whilst in the field without some excitement caused by these creatures and it was during the long process of ranging onto Capt Klopper's target (the number of rounds went into double figures) that further delay was caused when a shell shocked snake emerged from his lair right under the gun layer's feet. To see from a distance a gun detachment run in all directions from their gun in the middle of an engagement is somewhat disconcerting to say the least.

On the return journey the convoy had just swung into the steep main road leading into Mossel Bay to make its way to the camping area at the Point when the driver of a Mack stepped on the brake pedal preparatory to changing into a lower gear and found himself without brakes. With his heavy 10 ton vehicle already gathering momentum he swung out of line just missing the gun in front of him and with his gun's left wheel going up and 
over the right wheel of the gun his vehicle had just missed, he went hurtling down the road.

Thinking just as quickly, Captain de Gruchy swung his jeep and, hooter blaring, hurtled after the runaway tractor and gun. It was $16 \mathrm{h00}$ and one of those chances in a million when not one vehicle was moving on Mossel Bay's main business thoroughfare. Both vehicles blasted down the road through the town centre. The Mack went up the slight rise at the other end of town and came to a halt on the outspan at de Poort. A badly shaken driver was made to get back into his vehicle, uncomfortable pants and all, start up and park the vehicle under the orders of the Adjutant.

Included in the convoy were a couple of AEC Matador gun tractors. Four wheeled as compared to the Mack's 10 wheels, and not as impressive in appearance but never the less as tough as they come, and also tough to drive.

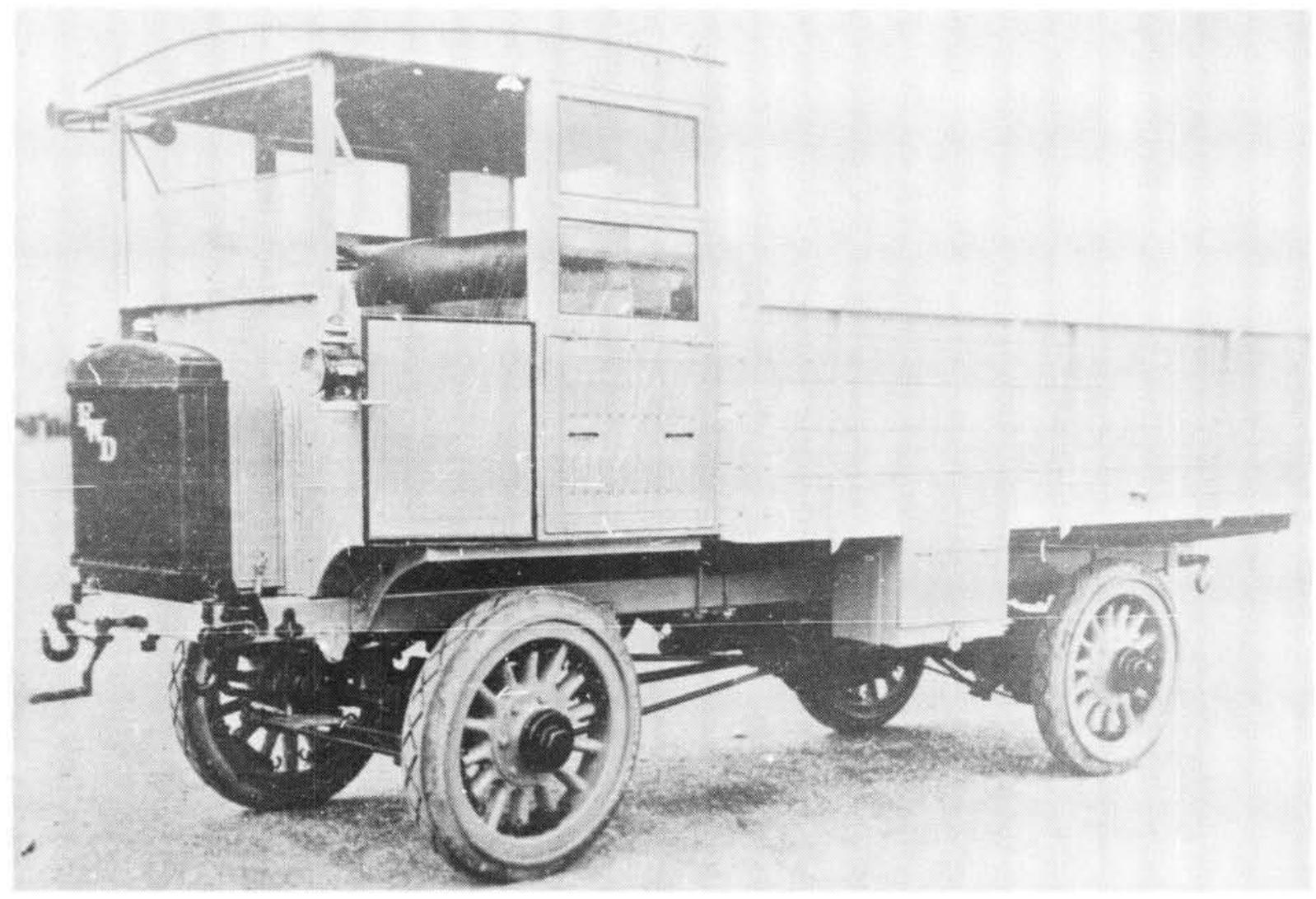

Four-wheel-drive lorry used as a tractor for Medium Artillery.

One matador, however, gave so much trouble and its diesel engine belched out so much black smoke, that it was named "Smoky Joe". It gave up the ghost and was left behind at Elgin and recovered days later.

A ceremonial drive through the City of Cape Town had been arranged and the unit laagered at Eerste Rivier aerodrome on Sunday night before entry into the city. To ensure there were sufficient vehicles the "break-downs" were recovered and repaired that night and in one operation a Mack was driven down Sir Lowry's Pass without brakes or lights and with only a jeep in front to light the way!

At the final staging point the next morning whilst waiting to move into the city a Mack sank into the boggy soil of Rondebosch Common and the 10 ton vehicle was winched out with ease by a Matador.

During the march-past at $11 \mathrm{~h} 00$ that day half of the 16 tractors (described as lorries by the Cape Argus of 21st May 1951) and guns had passed the City Hall where the Mayor, Mr C.O. Booth, 
took the salute when "a fault in the petrol feed of one of the 10 ton towing lorries upset the parade ..." so said the Argus and, "the rest of the convoy had to bypass it and by the time a 3-ton lorry had manoeuvred into position to take up the tow, traffic in Darling Street had been dislocated".

The same newspaper dramatically reported that "the lorries and $6 \frac{1}{2}$ ton guns in the parade were covered with dust and dirt after the long road journey from Oudtshoorn", but at least one former member of the regiment seems to recall having put much effort into cleaning guns and vehicles before they went into the city.

The regiment had some time prior to continuous training been declared an Afrikaans unit and much effort had been spent in the classrooms at Oudtshoorn translating gunnery terms from English. It was not wholly successful (Sgt Hook gave up on the Director once he had reached "butterflynut") but it certainly laid the foundations for future instruction and training in Afrikaans.

Appearing on the 1951 camp photograph were 2nd Lieutenants Vic van Es, Peter Key and Vernon Meyer, all commissioned with effect from 2nd April 1951. Their commissions, together with that of 2nd Lieutenant Michael McKiever, also commissioned into 1 Medium Regiment on the same date, may have been passed to the OC quickly enough to have the first three of these gentlemen available to him at camp but they were only notified to all concerned in Government Notice 2628 of 12 th October 1951.

The third "young gentleman" will long be remembered by those who knew him for the game of Russian Roulette in which he and one other were engaged on the lawn outside the Officers' Mess, which was stopped in the nick of time by Major Vosloo - the next pull of the trigger was "live" and on another occasion for the famous statement made while swaying on his feet, of "twenty four brandies and still on my feet", after which he literally collapsed for the night.

Unbeknown to the Mediums, Staff Sgt P.F. van der Merwe, known affectionately as "Platkop", commenced a three month course - Training NCO S.A.A. (f) PF - on 9th July 1951 preparatory to joining 1 Medium Regiment in place of Staff Sgt Reg Presmeg.

Lieutenant Walters attended the January 1952 qualifying course to Captain whilst 2nd Lieutenants Beineke, Crook and Key were also present at the School of Artillery and Armour over the same period attending a qualifying course to Lieutenant, the courses being held in hazardous cirmcumstances as the whole area occupied by the Officers Mess was "infested" with masses of bees hanging in huge swarms from the trees and bushes, under the eaves of bungalows and even inside rooms and furniture.

All four qualified but the less said about their stay in the Mess the better except to mention that one night all four ended up in the swimming pool in their undress blues pushing round a mattress on which, for a few minutes at least, had been a frightened Pretoria Highlander of 2 nd Anti-Tank Regiment who had been carried from his room in his bed and tipped bed and all, into the pool!

The kilted 22nd Field Regiment (S.A. Irish) were hosts for the practical field work of both courses but the Mediums felt they were so badly treated by the Commanding Officer that their bee expert, Willem Beineke, took a swarm and placed it in the bed of the S.A. Irish OC before the four departed by the midday train on Saturday, knowing that the field gunners were returning from the range that afternoon.

Amongst those who had attended the 1951 camp as recruits were Gunners Bannatyne and du Toit, both of whom were commissioned with effect from 21 February 1952, in time to take that year's convoy to Oudtshoorn, with 2nd Lieutenant du Toit as Convoy Leader. "Ouman" but newly commissioned Clive Francis was Advance Party $\mathrm{Cmdr}$, responsible for preparing the campsite and providing a hot meal each evening. 2nd Lieutenant Bannatyne had a tough first camp as a Commissioned Officer, acting as OC, Adjutant and $\mathrm{QM}$ to the new recruits until the arrival of the main body of the unit a couple of weeks later.

It was at this camp that Lieutenant van Es acquired a Harley Davidson motorcycle and seemingly spent his waking hours riding all over the camp and the veld. He became particularly adapt at firing his 38 pistol at various targets whilst in the saddle and also, because he and others were accommodated in a tent at the Officers' Mess with the light switch in the main building, at shooting out the globe each night. It is rumoured that towards the end of the camp the top of the tent was so full of holes, it finally collapsed.

The intervening months were occupied by train- 
ing parades and the usual social events, enlivened on one evening at the Castle when $\mathrm{Cmdt}$ Munnik invited a number of American Naval and Marine Officers and their partners who had been at an official reception in the Lady Anne Barnard rooms, to continue the party in the Medium Mess, the highlight of the unexpected but pleasant and amusing evening being when one lady took a swing at a cannon ball on the floor and broke the toes of her right foot.

Little did members of the unit know it but they attended their final camp as a Medium Regiment from 18th February to 31st March 1953, the recruits as usual being present for the whole period whilst the trained men and the Officers attended the final three weeks. For the first time in three years the Regiment moved to camp by rail as vehicles and guns and other equipment were in process of being handed in to depots in view of re-organisation of training staff and equipment.

In previous years training staff had been sent from Potchefstroom to Oudtshoorn when the three Cape based Gunner units, 1st Field Regiment (P.A.O.C.F.A.) and 1st Medium Regiment from Cape Town, and 5th Field Regiment from Port Elizabeth, went there for continuous training but in 1953 the units known as Training Depots at Potchefstroom, Bloemfontein and Oudtshoorn were disbanded and Training Regiments were set up in their place. 4 Field Training Regiment S.A.A. was established at Potchefstroom with 10th Field Battery S.A.A. "B" Squadron, ISSB and "C" Coy, 1SAl whilst 1 S.A. Infantry Training Battalion was established at Oudtshoorn with 12 Field Battery, 4 Field Regiment S.A.A., as part thereof. The Training Depot at Bloemfontein was replaced by ISSB Training Regiment.

Captain E.C.G. Brereton Stiles had headed the training team in 1951 as Chief Instructor Gunnery, whilst the imperturbable Capt Greyvenstein had been CIG the year after.

Once again it was an uneventful camp except that one gunner of Dog Troop, of which the Number One was later to become an RSM in Cape Field Artillery, fired $7^{\circ}$ off line on one target with the result that there were many badly frightened ostriches on a farm bordering the range.

The medium ammunition at that time weighed $100 \mathrm{lbs}$ and on one occasion, while unloading rounds from a Mack tractor, one Sergeant who thought he was tough and wished to impress his gunners told the man on the vehicle to let him have it. So a shell was dropped for him to catch. To his credit he caught it at the base but its weight took his hand to the ground and neatly clipped off three fingers.

The camp photograph shows 13 Officers, 4 Warrant Officers and 190 NCO's and Gunners excluding training staff. Included amongst the 2nd Lieutenants present were the former RSM, John Rath, a German who had fought in the 2nd AntiAircraft Regiment, S.A.A. in North Africa, and the irrepressible Noel Fiveash.

The hangar at Youngsfield finally emptied and Headquarters moved back to the building next to the New Drill Hall at Tennant Street, Cape Town.

By this time several Officers had completed their compulsory term of service and had been transferred to the Reserve or had been posted to other units because of business transfers and the July 1953 roll of Officers and Warrant Officers read as follows:

Cmdt: $\quad$ N.E. Munnik, ED

Major: A.G. Vosloo, MC and J.J. Crouse

Captain: A.H. de Wet; Z. Nel and T. Walters

Lieuts: W.F. Beineke; L.A. Crook; L.E. Hawtrey; P.J. Potgieter; J. Rath; V.H. van Es

2nd Lieuts: W. Bannatyne; J.L. Chivell; T.L.E. du Toit; C.J. Francis; N.K. Fiveash; P.J.C. Key, N.K. Loubser

W01: G.L. Heydenrych

WO2: $\quad$ C.J. Marais; L.T. Swanepoel

Lieutenant John Rath was Adjutant and Lieutenant Vic van Es was Quartermaster.

At the September meeting of Officers, held on the first Thursday of every month in the "Castle Combined Artillery Officers Mess", as it was called (it was shared with 1st Coast Regiment, S.A. Marines and with Cape Field Artillery), V.W. Meyer, $P$. Leigh and $H$. Salmon all former Officers were welcomed as visitors.

At the previous month's meeting officers had been told that the annual Regimental Dance held in the New Drill Hall had been attended by 122 couples, bar takings had been £36-8-0 $(R 72,80)$ and sale of tickets had realised £125 (R250). The Dance Committee Chairman, Major 
Vosloo, indicated that the estimated profit would be £42-5-0 (R84,50).

The meeting agreed to support the Garrison Officer's Mess Dance and the Cape Field Artillery 96th Birthday Dance later in the year and finally noted that no progress was being made to obtain the Mess for their own use as the "Cape Field Regiment" was unable to find other accommodation. "It is our Regiment's intention to acquire both rooms with as much of the furniture as possible", so read Minute IV of that meeting.

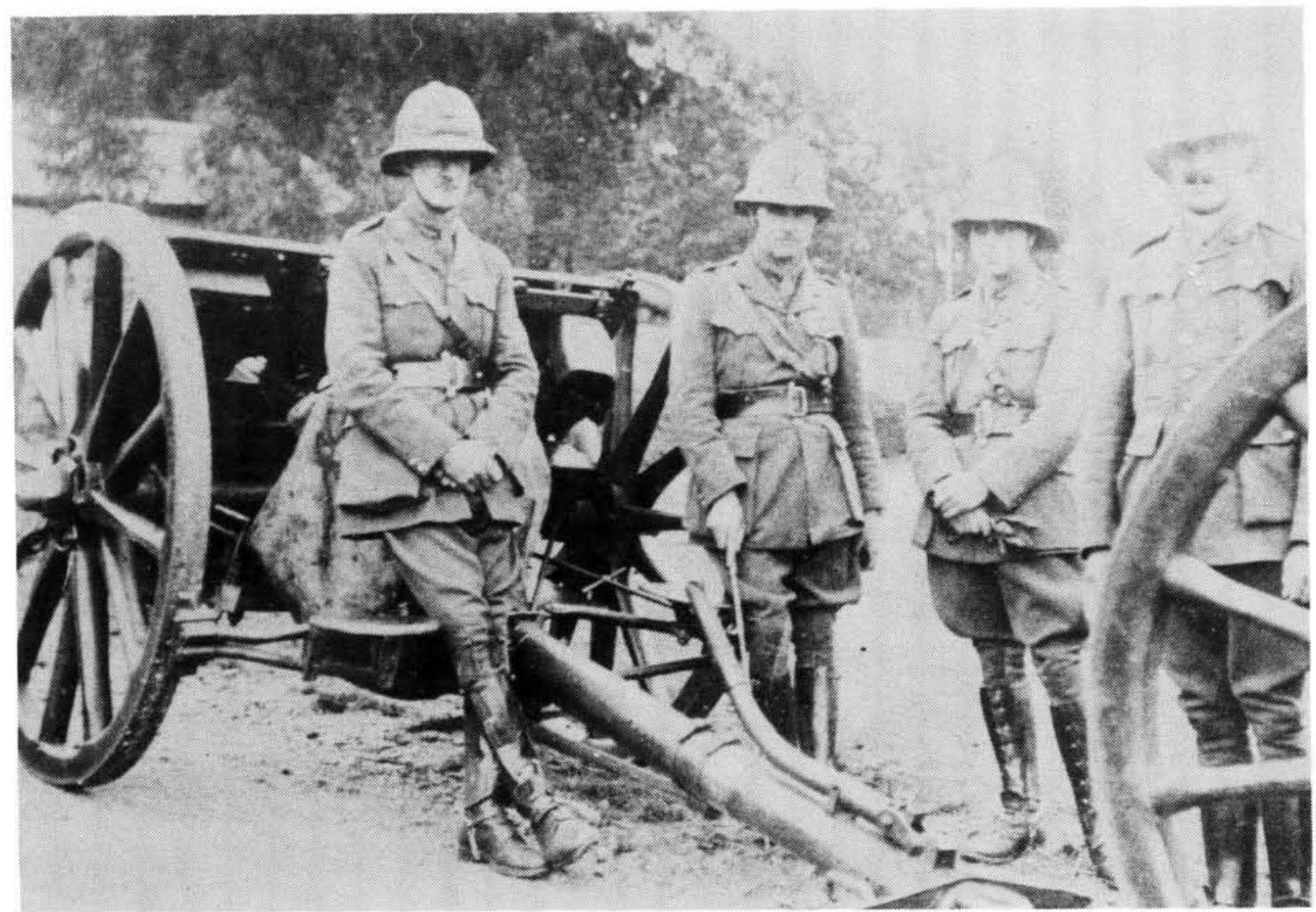

Cape Fleld Artillery Officers and gun.

In October the question of a separate Mess for Cape Field Artillery and the Mediums claim to half the furniture was still being discussed with Cmdt Munnik himself actively trying to find a Mess for the use of CFA.

Regimental funds could not have been too strong for the October minutes reveal that while The Gunner's Association had lent the Regiment R200 in 1946 when the Regiment was formed and which had just been repaid, the unit was only able to donate R10,50 to the Association's national appeal for R722 to complete the Gunners' Memorial at Potchefstroom.

The following month Cmdt Munnik read a "beledigende brief", the minutes were later changed to read "hooghandige brief", received from the 1st Coast Regiment in which they claimed all furniture in the Mess. A suitable reply had been sent and OC Cape Command had stepped in and declared that no furniture would be removed at all.

Before the meeting ended that Thursday, 5th November 1953, the Commanding Officer announced the sad news that 1 Medium Regiment was being transferred to Outeniqua Command and that Officers would be placed on the General List. It was an obvious shock to the officers and the meeting noted the news and asked, "dat die naam van die Regiment nie weer aldaar gebruik sal word nie".

The young and very proud Regiment did not lay down and cease activities as could so easily have happened but soldiered on to the bitter end. The question of the furniture was discussed at their very last Mess meeting on 3rd December and Capt Walters was asked to liaise with the $\mathrm{OC}$ and prepare a memorandum outlining the 
situation as decided at the recent meeting, noting that the furniture removed by the S.A. Marines would be considered on temporary loan to them. It was also noted that the miniature Coast Cannon had been removed by the Marines and had to be returned as it was 1 Medium property.

Responding to Minute XX Cmdt Munnik said that no definite answer had been received to the written request that the name of 1 Medium Regiment not be used for the new regiment at Oudtshoorn but that Cape Command had had the audacity to return the letter to the unit under the pretence that it was undesirable. A suitale reply had, however, been despatched by Major Vosloo.

Finally the Officers decided that a compulsory Cocktail party would be held on 28th December, that the Monday evening lectures would carry on until 14 December as planned and that the parade of Saturday 12th December would be an afternoon parade only, when all other ranks would be told what was to happen to the Regiment.

The last official get-together of the Officers was at Capt Zirk Nel's wedding on 16 January 1954. And so Cape Town lost its only Afrikaans speaking unit of any importance when 1 Middelslagregiment S.A.A. (S.A.H.A.) was transferred to Oudtshoorn with effect 31 December 1953, just 8 years after it had been established. It had in that time built up an enviable reputation as a dynamic disciplined unit under the able leadership of a well-loved but stern Commanding Officer.

In a letter dated 23 January 1954, approval was given for the transfer of 1 Medium Officers to 1 Field Regiment (P.A.O.C.F.A.), S.A.A. with effect from 1st January of that year and for the cancellation of their transfer to the General List, S.A.A.

The same letter also provided for the reposting of the seven remaining Officers of 1 Field Regiment in order to accommodate those from 1 Medium.
A letter dated from Cape Command two days later confirmed that it would be impossible to find an Artillery Commanding Officer at Oudtshoorn and agreed that $\mathrm{Cmdt}$ Munnik would be reinstated as OC; furthermore that two or three former 1 Medium Officers would be allowed to transfer back to the unit after 1 Field Regiment's 1954 period of continuous training to assit in the selection and training pf junior Officers. One of those who rejoined Cmdt Norman Munnik was Vic van Es.

It was a fortunate marriage for 1 Field Regiment (P.A.O.C.F.A.), S.A.A., who were brought up to full strength as a result of the influx of Officers, WO's, NCO's and gunners.

Seven future Commanding Officers were amongst the Officers and WO's who transferred, although two would not command CFA itself, but one, a Rhodesian Infantry Unit and WO Chris Marais, a Transvaal Artillery Unit.

Strangely enough 1st Medium Regiment, South African Artillery, (S.A.H.A.) was renamed with effect 1st January 1954, to become 1 Medium Regiment (S.A.H.A.), S.A.A. It was not sufficient, however, to satisfy former members.

Little or nothing is known of its doings during the next few years but it was finally disbanded and disestablished on 1st March 1960, when the Citizen Force once again suffered re-organisation.

As a result of the disbandment of the Unit Colonel F.W. Mellish, MC relinquished the appointment of Honorary Colonel from that date and one of the Officers, Captain George Gravett transferred to Cape Field Artillery joining his new unit in the middle of the 1960 emergency.

The name of 1 st Medium Regiment, South African Artillery (S.A.H.A.), and of its charismatic Commander will live on in the minds and hearts of the Happy Mediums.

\footnotetext{
* The writer joined 1 Medium Regiment in July 1949 and is still serving as a volunteer in the South African Artillery (Citizen Force).
} 